\title{
Effects of unpleasant emotional exposure on the state anxiety and heart rate in
}

\section{healthy women: a pilot study}

\author{
Efeitos da exposição a estímulos desagradáveis no estado de ansiedade e frequência cardíaca em \\ mulheres aparentemente saudáveis: um estudo piloto \\ Efectos de la exposición a estímulos desagradables sobre el estado de ansiedad y la frecuencia
} cardíaca em mujeres aparentemente sanas: un estudio piloto

Received: 11/30/2021 | Reviewed: 12/08/2021 |Accept: 12/10/2021| Published: 12/17/2021

\author{
Ricardo Borges Viana \\ ORCID: https://orcid.org/0000-0001-9200-3185 \\ Universidade Estadual de Goiás, Brasil \\ Faculdade Estácio de Sá de Goiás, Brasil \\ E-mail: vianaricardoborges@hotmail.com \\ Naiane Silva Morais \\ ORCID: https://orcid.org/0000-0002-4210-4938 \\ Universidade Federal de Goiás, Brasil \\ E-mail: morais.nsm@gmail.com \\ Thalles Guilarducci Costa \\ ORCID: https://orcid.org/0000-0003-2542-8903 \\ Universidade Federal de Goiás, Brasil \\ E-mail: profthallesgc@gmail.com \\ Lucas Carrara do Amaral \\ ORCID: https://orcid.org/0000-0002-2173-0235 \\ Universidade Federal de Goiás, Brasil \\ E-mail: lucascarrara23@gmail.com \\ Wellington Fernando da Silva \\ ORCID: https://orcid.org/0000-0002-7793-2274 \\ Universidade Federal de Goiás, Brasil \\ E-mail: wellingtonedfisica2@gmail.com \\ Douglas Assis Teles Santos \\ ORCID: https://orcid.org/0000-0002-7664-5468 \\ Universidade do Estado da Bahia, Brasil \\ E-mail: datsantos@uned.br \\ Claudio Andre Barbosa de Lira \\ ORCID: https://orcid.org/0000-0001-5749-6877 \\ Universidade Federal de Goiás, Brasil \\ E-mail: andre.claudio@gmail.com
}

\begin{abstract}
Considering that exposure to unpleasant pictures taken from the International Affective Pictures System (IAPS) has a more significant impact on anxiety than exposure to pleasant and neutral pictures, we investigated changes in state anxiety levels and heart rate responses in healthy women following exposure to three blocks of unpleasant pictures from the IAPS. Thirty-seven healthy women visited the lab three times, separated by a gap of 24-72 hours. Anxiety levels were assessed using the State Anxiety Inventory before and after participants viewed the blocks of unpleasant IAPS pictures, while the heart rate was continuously monitored throughout each session by a heart rate monitor. We found extreme evidence $\left(\mathrm{BF}_{10}=7.53 * 10^{8}\right)$ for the changes in the participants' state anxiety after viewing IAPS unpleasant pictures, although there was ambiguous evidence $\left(\mathrm{BF}_{01}=2.642\right)$ favoring similar changes in state anxiety and ratings of pleasure $\left(\mathrm{BF}_{01}=1.567\right)$, arousal $\left(\mathrm{BF}_{01}=2.609\right)$, and dominance $\left(\mathrm{BF}_{01}=1.954\right)$ between the three blocks of unpleasant pictures used. Moreover, we found moderate evidence $\left(\mathrm{BF}_{01}=7.449\right)$ favoring similar mean heart rates between the three blocks of unpleasant pictures. These findings reveal that exposure to unpleasant pictures can act as an anxiogenic stimulus used to induce experimental anxiety.
\end{abstract}

Keywords: Anxiety; Emotion; Mood disorders; Mental disorders; Stress.

\section{Resumo}

Considerando que a exposição a imagens desagradáveis disponíveis no International Affective Pictures System (IAPS) tem um impacto mais significativo na ansiedade do que na exposição a imagens agradáveis e neutras, investigamos mudanças nos níveis de ansiedade-estado e respostas de frequência cardíaca em mulheres saudáveis após a exposição 
a três diferentes blocos de imagens desagradáveis do IAPS. Trinta e sete mulheres saudáveis visitaram o laboratório três vezes, com um intervalo de 24 a 72 horas entre as visitas. Os níveis de ansiedade antes e após visualização dos blocos de imagens desagradáveis do IAPS foram avaliados por meio do State Anxiety Inventory, enquanto a frequência cardíaca foi monitorada continuamente ao longo de cada sessão por meio de um monitor de frequência cardíaca. Encontramos evidências extremas $\left(\mathrm{BF}_{10}=7,53 * 10^{8}\right)$ para as mudanças na ansiedade estado das participantes antes versus após a visualização das imagens desagradáveis do IAPS, embora tenha havido evidências ambíguas $\left(\mathrm{BF}_{01}\right.$ $=2,642$ ) favorecendo mudanças semelhantes na ansiedade e classificação do estado de prazer $\left(\mathrm{BF}_{01}=1,567\right)$, excitação $\left(\mathrm{BF}_{01}=2,609\right)$ e dominância $\left(\mathrm{BF}_{01}=1,954\right)$ entre os três blocos de imagens desagradáveis utilizadas. Além disso, encontramos evidências moderadas $\left(\mathrm{BF}_{01}=7,449\right)$ a favor de frequências cardíacas médias semelhantes entre os três blocos de imagens desagradáveis. Esses achados revelam que a exposição a imagens desagradáveis pode atuar como um estímulo ansiogênico usado para induzir ansiedade experimental.

Palavras-chave: Ansiedade; Emoção; Transtornos de humor; Transtornos mentais; Estresse.

\section{Resumen}

Mientras que la exposición a imágenes desagradables tomadas del International Affective Pictures System (IAPS) tiene un impacto más significativo en la ansiedad que en la exposición a imágenes agradables y neutras, investigamos los cambios en los niveles de ansiedad en el estado y las respuestas de frecuencia cardíaca en mujeres sanas después de la exposición a tres bloques de imágenes desagradables de IAPS. Treinta y siete mujeres sanas visitaron el laboratorio tres veces, separadas por 24 a 72 horas. Los niveles de ansiedad se evaluaron utilizando el State Anxiety Inventory, antes y después de la visualización de los bloques de imágenes desagradables del IAPS, mientras que la frecuencia cardíaca se monitoreó continuamente a lo largo de cada sesión mediante un monitor de frecuencia cardíaca. Se encontró evidencia extrema $\left(\mathrm{BF}_{10}=7,53 * 10^{8}\right)$ para cambios en el estado de ansiedad de los participantes, comparando antes y después de la visualización de las imágenes desagradables de la IAPS, aunque hubo evidencia ambigua $\left(\mathrm{BF}_{01}=2,642\right)$ a favor de cambios similares en la ansiedad y la clasificación del estado de placer $\left(\mathrm{BF}_{01}=\right.$ 1.567), la excitación $\left(\mathrm{BF}_{01}=2,609\right)$ y la dominancia $\left(\mathrm{BF}_{01}=1.954\right)$ entre los tres bloques de imágenes desagradables utilizados. Además, se encontró evidencia moderada $\left(\mathrm{BF}_{01}=7,449\right)$ a favor de una frecuencia cardíaca media similar entre los tres bloques de imágenes desagradables. Estos hallazgos revelan que la exposición a imágenes desagradables puede actuar como un estímulo ansiogênico utilizado para inducir ansiedad experimental.

Palabras clave: Ansiedad; Emoción; Trastornos del estado de ánimo; Trastornos mentales; Estrés.

\section{Introduction}

Anxiety is one of the most frequent psychiatric conditions (Bandelow \& Michaelis, 2015; Mondin et al., 2013) defined as apprehension, tension, or uneasiness from the anticipation of danger (American Psychiatric Association, 2013). An increase in anxiety levels can be induced experimentally using various methods (Charney et al., 1984; Motl \& Dishman, 2004; Smith, 2013; Smith et al., 2005; Youngstedt et al., 1998). Traditionally, caffeine ingestion has been demonstrated to be effective in increasing anxiety levels (Charney et al., 1984; Motl \& Dishman, 2004; Youngstedt et al., 1998). In a seminal study, Charney et al. (1984) examined the mechanism of action of behavioral reactions to caffeine and how such effects are related to caffeine's ability to produce anxiety in healthy individuals. The authors reported that compared with a placebo, the oral administration of caffeine $(10 \mathrm{mg} / \mathrm{kg})$ significantly increased mean ratings of anxiety from baseline levels. In another study, Motl and Dishman (2004) investigated the effects of a moderate-intensity cycling exercise on the soleus H-reflex and state anxiety in healthy individuals by experimentally manipulating anxiety via the consumption of a large dose of caffeine. The results revealed that caffeine consumption did not influence the amplitude of the soleus H-reflex but did increase state anxiety.

Another mode to induce negative emotional states is by watching film clips. Sarlo et al. (2005) exposed 34 healthy undergraduates (women and men) to four sound film clips, which include mutilation (part of a medical documentary showing a thoracic operation), contamination (cockroach invasion), fear (a boy threatened by a man with a knife), and neutral (part of a landscape documentary), with a random intertrial interval (4-6 minutes) of blank screen lapsed between film presentations. Each film clip was presented for 132 seconds, preceded by a blank screen of $60 \mathrm{~s}$. The authors used the paper-and-pencil version of the Self-Assessment Manikin (SAM) to rate the valence and arousal of each picture, and a five-point paper-andpencil scale to evaluate six basic emotional states (happiness, surprise, fear, anger, disgust and, sadness) in reaction to the film 
clips. The results indicated that fear, mutilation, and contamination film clips were rated as more unpleasant and arousing than neutral, with no significant differences among each other.

In addition to caffeine ingestion and film clips, another mode to increase negative emotional states (e.g., anxiety levels) is via picture stimuli (Smith, 2013; Smith et al., 2005). Using pictures from the International Affective Picture System (IAPS) (Lang et al., 1997, 2008b), Smith et al. (2005) demonstrated that sustained exposure to emotional stimuli (e.g., unpleasant pictures) is an effective strategy for increasing anxiety levels in introductory psychology students. The IAPS (Lang et al., 1997, 2008b) was created to be an easy, useful, and standard tool for eliciting emotional states, because using different experimental procedures in studies (i.e., caffeine dose) hinders the comparison of the results. The IAPS comprises a series of pleasant, neutral, and unpleasant (e.g., mutilations, accidents, funerals, burn victims, sad children, dead bodies, organs, injuries, threats, assaults, and aimed guns) pictures that may elicit emotional states, similar to how real-life events do it (Cuthbert et al., 1996; Lang et al., 1997, 2008b). Thus, as reported by Jayaro et al. (2008), "[...] the affective pictorial information may match the stimulating properties of real situations, giving rise in the same way to the activation of cognitiveperceptual representations associated with emotional responses."

In this context, the IAPS is an efficient instrument for inducing emotional states such as varying anxiety levels (Smith, 2013; Smith et al., 2005) owing to the possible combinations of over 1,800 pictures. For example, Smith et al. (2005) used 144 IAPS pictures (36 pleasant, 72 neutral, and 36 unpleasant) to elicit anxiety levels, whereas, in a later study, Smith (2013) used only 90 IAPS pictures (30 pleasant, 30 neutral, and 30 unpleasant). Considering that those studies did not use identical pictures, the different combinations of IAPS pictures might have resulted in different increases in anxiety levels found.

Furthermore, anxiety crisis is often accompanied by alterations in physiological parameters, such as an abnormally increased heart rate. Taylor et al. (1986) found that 58\% of "panic" attacks reported by walk-in patients during six days "occurred at heart rates disproportionate to activity levels and different enough from surrounding heart rates to indicate a distinct physiologic state." More precisely, heart rate changes occurred during self-reported panic attacks.

Therefore, the studies using IAPS revealed a more considerable effect on anxiety following exposure to unpleasant pictures (Smith et al., 2005). Considering that women are approximately $60 \%$ more likely than men to develop anxiety during their life (NIMH, 2016), we aimed to investigate, in this pilot study, changes in levels of state anxiety in healthy women following exposure to three blocks of unpleasant pictures from the IAPS. If these blocks of unpleasant pictures do increase anxiety levels, they could be used in a nonrepetitive fashion in within-group design studies aimed at inducing experimental anxiety. A secondary aim was to investigate the heart rate behavior during exposure to these pictures.

\section{Methodology}

\subsection{Participants}

Thirty-seven healthy women were recruited through advertisements on social media and word of mouth. The inclusion criteria were as follows: (i) being a woman and (ii) being between 18 and 40 years old. The exclusion criteria were as follows: (i) menstruating at the time of the study, because participants could have been negatively influenced by the premenstrual phase, associated with an increase in negative psychological symptoms (e.g., anxiety) (Nillni et al., 2011) and (ii) not being currently clinically diagnosed with anxiety and/or other mental disorders, according to the self-reports of participants. All participants were within the normal range on trait anxiety (mean: 44, standard deviation: 9, range: 29-68), which measures proneness to experiencing anxiety symptoms. Additional information about the characteristics of the participants is shown in Table 1. 
Table 1. Characteristics of participants $(n=37)$.

\begin{tabular}{lcc}
\hline & Mean \pm standard deviation & Minimum-Maximum \\
\hline Age (years) & $28.6 \pm 5.7$ & $18.2-40.0$ \\
Height $(\mathrm{m})$ & $1.62 \pm 0.07$ & $1.41-1.82$ \\
Body mass $(\mathrm{kg})$ & $61.8 \pm 16.3$ & $37.3-111.1$ \\
Body mass index $\left(\mathrm{kg} / \mathrm{m}^{2}\right)$ & $23.4 \pm 5.4$ & $14.9-40.3$ \\
Trait anxiety score $(20$ to 80$)$ & $44 \pm 9$ & $29-68$ \\
Use of contraceptive & & - \\
$\quad$ Number of participants* & $13(35.1 \%)$ & $5.0-180$ \\
Time of use (months) & $48.1 \pm 47.5$ & $1-1095$ \\
Days after menstruation period ${ }^{\mathrm{a}}$ & $67 \pm 198$ & - \\
Contraceptive type* & & - \\
$\quad$ DIU - Mirena & $3(8.1 \%)$ & - \\
Siblima - Tablet & $2(5.4 \%)$ & - \\
Alestra - Tablet & $2(5.4 \%)$ & - \\
Ferani - Tablet & $1(2.7 \%)$ & - \\
Yasmin - Tablet & $1(2.7 \%)$ & - \\
Selene - Tablet & $2(5.4 \%)$ & - \\
$\quad$ Jalisa - Tablet & $1(2.7 \%)$ & - \\
\hline
\end{tabular}

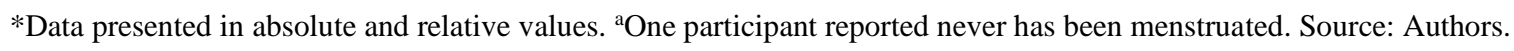

Informed consent was obtained from all participants and all experimental procedures were approved by the Federal University of Goiás Research Ethics Committee (approval number: 91446318.4.0000.5083) and conformed to the principles outlined in the Declaration of Helsinki.

\subsection{Study design}

A within-subjects experimental design was used. Each participant visited the lab three times separated by 24 to 72 hours, where anxiety levels were assessed before and after viewing a block composed of only unpleasant pictures from the IAPS (Lang et al., 2008b). An interval of at least 24 hours between visits was adopted as state anxiety is a transitory feeling with rapid changes (Spielberger, 1989). Three different blocks of pictures were compiled and balanced according to the normative valence values provided by the IAPS. In each session, only one block of pictures was used, and the pictures were randomized according to six possible block orders (1-2-3; 1-3-1; 2-1-3; 2-3-1;3-1-2; and 3-2-1) and their presentation lasted 30 minutes in total. State anxiety was assessed immediately before and after exposure to the pictures. Each first session, regardless of the block of pictures used, lasted approximately 15 minutes longer than subsequent sessions to allow the participants to read and sign the informed consent and for anthropometric measures to be taken. Familiarization with the paperand-pencil version of the Self-Assessment-Manikin (SAM) (Lang et al., 2008b), a scale used to rate dimensions of pleasure, arousal, and dominance of each picture, was performed in each session.

Visual/verbal instructions and familiarization with the SAM (Lang et al., 2008b) took place after the pre-state anxiety level assessment of the first session. In the second and third sessions, only the instructions for rating the unpleasant pictures were repeated. All information, including the duration of their exposure to the unpleasant pictures, SAM scale, and time duration for rating each unpleasant picture, was presented in a Microsoft PowerPoint presentation on a TV screen. All pictures used during familiarization were extracted from public domain websites. During familiarization and the experiment proper, participants remained seated in a chair located two meters from the TV (Philips, 42PFL3507D/78, Brazil). The heart rate was continuously monitored throughout each session by a heart rate monitor (model V800, Polar, Finland) (Figure 1). 
Figure 1. Flowchart of the study. (A) Number corresponding to the picture to be displayed, (B) displayed picture to be rated, and (C) warning to rate the previously displayed picture. STAI: State and Trait Anxiety Inventory. IAPS: International Affective Pictures System. SAM: Self-Assessment Manikin. HR: heart rate.

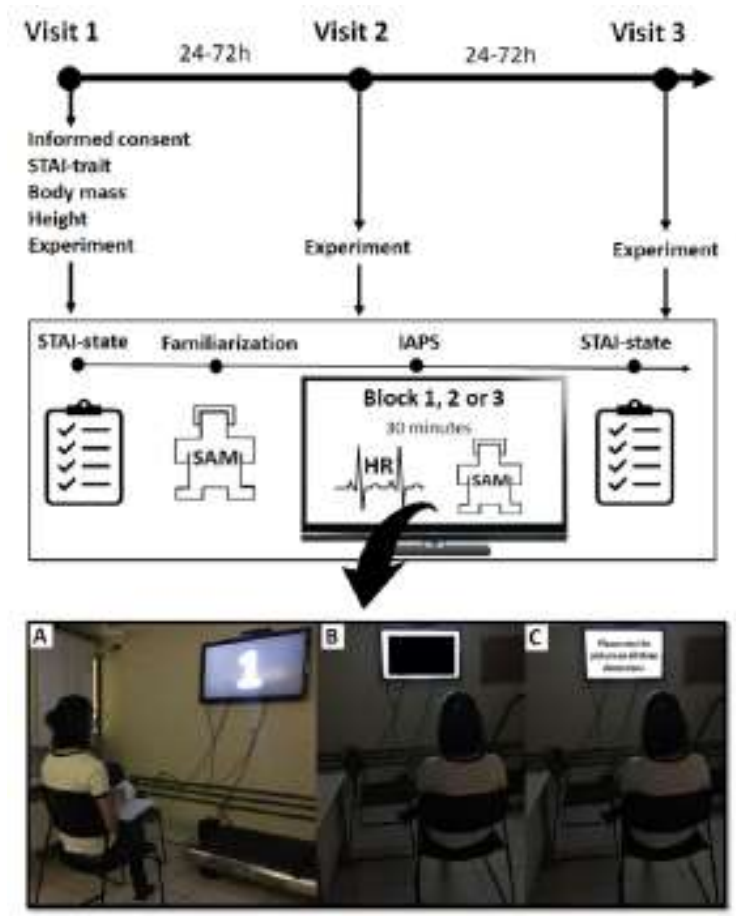

Source: Authors.

All experimental procedures were completed within one week. All participants were instructed to refrain from eating two hours before each experimental session and abstain from caffeine, alcohol, and physical activity for 24 hours before each session. The temperature and relative humidity in the lab ranged from $21{ }^{\circ} \mathrm{C}$ to $23{ }^{\circ} \mathrm{C}$ and $55 \%$ to $65 \%$, respectively. We performed the sessions in the mornings and the afternoon; however, the three visits of each participant were conducted at the same time of the day to respect their circadian rhythm.

\subsection{State and trait anxiety assessment}

Symptoms of state and trait anxiety were assessed by the State-Trait Anxiety Inventory (STAI) (Spielberger, 1989), translated and validated for the Brazilian Portuguese population by Gorenstein and Andrade (1996). State and trait anxiety scale assesses how individuals feel "right now, that is, at this moment" and "generally." In the first visit, participants sat in a sound-attenuated room and were instructed to answer all questions of the state and trait anxiety scale items according to how they felt "right now; that is, at this moment" (state anxiety) and "generally" (trait anxiety), respectively. In the second and third visits, only state anxiety was assessed before and immediately after viewing the blocks of unpleasant pictures. In summary, state and trait anxiety scale items assess subjective feelings of calm, tension, apprehension, nervousness, worry, and other items related to autonomic nervous system activity. State and trait anxiety scale items are rated on a 4-point Likert scale $(1=$ not at all, 2 = somewhat, $3=$ moderately so, and 4 = very much so) (Spielberger, 1989). STAI scores vary from a minimum of 20 to a maximum of 80 . Scores of $\leq 30$, between 31 and 49 , and $\geq 50$ indicate low, intermediate, and high levels of anxiety, respectively (Spielberger, 1989). We chose the STAI because it has been used in many different disciplines to measure trait and state anxiety and translated into 30 languages (Spielberger, 1989). Also, the STAI-state was found to be positively correlated with the Anxiety Sensitivity Index (Peterson \& Reiss, 1987), and has an easy application and low cost. 


\subsection{The International Affective Picture System (IAPS)}

In each session, participants viewed one block of pictures made up of 69 different unpleasant pictures taken from the IAPS (Lang et al., 1997, 2008b). The unpleasant nature of all pictures used in the present study was determined by two of the researchers (R.B.V. and C.A.B.L.) according to the pleasure/arousal/dominance values and picture description category (e.g., mutilations, accidents, funerals, burn victims, sad children, dead bodies, organs, injuries, threats, assaults, and aimed guns) from the IAPS. Overall, the IAPS has more than three unpleasant pictures for each description category. Therefore, we selected pictures from each category (e.g., lower pleasure, lower dominance, and higher arousal score) and these pictures were allocated to one of the three blocks of pictures (Table 2). Any disagreement between the two researchers was solved by consensus after a short discussion. The IAPS is a widely used source of visual stimuli for inducing emotions in laboratory settings and a validated reliable instrument for experimental studies in the Brazilian population (Lasaitis et al., 2008). Furthermore, repeated exposure to unpleasant IAPS pictures has been found to induce a change in mood and is sensitive to early-stage anxiety (Smith et al., 2005). All procedures were conducted following the recommendations of Lang et al. (2008).

Table 2. IAPS identification number of the 207 unpleasant pictures used.

\begin{tabular}{ll}
\hline & IAPS Identification number \\
\hline Block 1 & $1300,3000,2730,3500,3062,9320,1050,3010,3160,3530,3064,9373,1201,3060,9300,6350,3110,9570,1120,3015$, \\
& $3170,6550,3071,9340,1052,3053,9008,6313,3130,9042,1220,3030,3266,6560,3102,9040,6212,6520,9005,9921$, \\
& $9433,3225,1304,2717,1930,3168,2800,3180,3191,6570,9265,3022,9412,1280,3061,2095,6022,2345,6821,8230$, \\
& $9007,6020,3103,1820,2722,3350,3250,6190,9180$. \\
Block 2 & $1525,2055,2276,6200,6021,9301,1114,2352.2,2205,6211,3400,3550,1205,3120,9322,6510,9428,9571,1040,3001$, \\
& $2900,6540,3068,9342,1070,3005.1,9325,4664.2,3061,3063,1202,3069,3080,2683,3101,2490,2301,6300,9006$, \\
& $9902,3016,3140,1301,2710,1932,3261,3301,6561,6360,6213,3131,2799,3017,9181,3150,2661,3051,2703,2691$, \\
Block 3 & $8231,6311,6840,9490,1310,6010,2718,3213,6562,9183$. \\
& $1321,9253,9075,2811,3059,9326,1051,9252,9432,6571,9250,3019,1200,9420,9302,3195,3100,9561,1022,6831$, \\
& $9341,3185,9491,9290,1111,9410,9321,3191,9163,9405,1240,9254,9530,9414,9635.1,9330,6838,6415,9102,9940$, \\
& $9440,9400,9185,9590,1931,9415,9520,6312,9041,6231,9430,9421,9413,1270,9435,9043,9445,9429,9423,9427$, \\
& $9584,9402,8480,9140,3220,2810,2981,6230,9182$.
\end{tabular}

IAPS: International Affective Picture System. Source: Authors.

\subsection{The Self-Assessment Manikin (SAM)}

The ratings of each picture on the dimensions of pleasure, arousal, and dominance were performed using a paper-andpencil version of the SAM. In brief, this version is a nine-point rating scale composed of graphically rendered, unlabeled dimensions of pleasure, arousal, and control/dominance, and each dimension was ordinally scaled to include five measurement points (Lang et al., 2008b). Participants can select any point by placing an "X" on or between any of the points (Lang et al., 2008b). Each block of pictures began with a preparation slide (in Microsoft PowerPoint format) presenting the picture number for five seconds. Subsequently, the picture to be rated was then presented for six seconds, followed by a slide with the following instruction: "Please rate the picture on all three dimensions." Participants had 15 seconds to make their ratings of pleasure, arousal, and dominance using the SAM. Considering that the IAPS presents pleasure, arousal, and dominance values, SAM assessment was used as a positive control to ensure that pictures selected were really unpleasant.

According to the IAPS, all 207 pictures (three blocks of 69 pictures) presented were unpleasant (lower pleasure, higher arousal, and lower dominance), and consequently, the three blocks of selected pictures presented a lower pleasure, higher arousal, and lower dominance (Table 3). All the slides were automatically programmed, and the total duration of each session was approximately 30 minutes. Participants were instructed to look at the pictures on the TV screen for the entire time that they were visible (six seconds). The duration of exposure to the pictures was in line with that adopted by previous studies (Smith, 2013; Smith et al., 2005). Before the pictures were shown, participants received a clipboard with the paper-and-pencil version of the SAM scale and were instructed not to talk during the experiment. In addition, there was no communication 
between the participants and the researchers while the pictures were being shown. Finally, the ambient lighting was dimmed to improve the visibility of the pictures (Figure 1).

Table 3. Mean and standard deviation of the pleasure, arousal, and dominance domains for each of the three blocks of pictures used.

\begin{tabular}{|c|c|c|c|c|c|c|}
\hline & \multicolumn{2}{|c|}{ Pleasure $^{a}$} & \multicolumn{2}{|c|}{ Arousal $^{\mathrm{a}}$} & \multicolumn{2}{|c|}{ Dominance $^{a}$} \\
\hline & Mean & SD & Mean & SD & Mean & SD \\
\hline Block 1 (69 pictures) & 2.12 & 0.80 & 6.38 & 0.82 & 3.35 & 0.76 \\
\hline Block 2 (69 pictures) & 2.27 & 0.73 & 6.08 & 0.80 & 3.39 & 0.71 \\
\hline Block 3 (69 pictures) & 2.38 & 0.76 & 6.00 & 0.80 & 3.50 & 0.75 \\
\hline
\end{tabular}

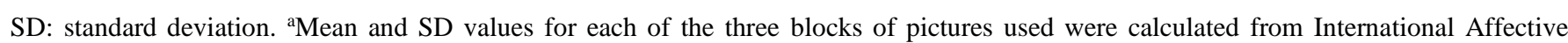
Picture System (IAPS) values for females. Source: Authors.

\subsection{Heart rate assessment}

Heart rate was evaluated using a heart rate monitor (model V800, Polar, Finland) attached to the participants' xiphoid process throughout each session. After each session, the data were downloaded to a personal computer.

\subsection{Statistical analysis}

Bayesian repeated measures analysis of variance (ANOVA) with two within-group factors (time [pre versus postsession] and blocks of unpleasant pictures [block 1 versus block 2 versus block 3]) and a "default Cauchy prior" of 0.5 (van Doorn \& Wagenmakers, 2020) was computed to compare state anxiety levels between blocks 1, 2, and 3. Bayesian repeated measures ANOVAs with a "default Cauchy prior" of 0.5 were also computed to compare changes in anxiety levels, mean SAM scores, and mean heart rate between blocks 1,2 , and 3. Bayes factors $\left(\mathrm{BF}_{10}\right)$ were used to provide evidence for or against the null hypothesis (Wagenmakers et al., 2018). More precisely, $\mathrm{BF}_{10}$ indicates the Bayes factor in favor of alternative hypothesis $\left(\mathrm{H}_{1}\right)$ over null hypothesis $\left(\mathrm{H}_{0}\right)$, whereas $\mathrm{BF}_{01}\left(\mathrm{BF}_{10}=1 / \mathrm{BF}_{01}\right)$ indicates the Bayes factor in favor of $\mathrm{H}_{0}$ over $\mathrm{H}_{1}($ van Doorn et al., 2020). Bayes factors range from 0 to $\infty$ and higher values of $\mathrm{BF}_{10}$ indicate more support for $\mathrm{H}_{1}$ (van Doorn et al., 2020). For example, a $\mathrm{BF}_{10}$ of " 3 " implies that the observed data are three times more likely under an alternative hypothesis than under the null hypothesis (Wagenmakers et al., 2018). Conversely, a $\mathrm{BF}_{10}$ of 0.33 implies that the observed data are three times more likely under the null hypothesis than under an alternative hypothesis (Wagenmakers et al., 2018). In the present study, the $\mathrm{H}_{0}$ is represented by a similar increase in state anxiety, similar mean heart rate, and similar SAM domains values across the three blocks of unpleasant pictures, whereas the $\mathrm{H}_{1}$ is represented by a different increase in state anxiety, different mean heart rate, and similar SAM domains values across the three blocks of unpleasant pictures. In addition, we computed model-averaged results across all models (van den Bergh et al., 2020). Inclusion Bayes factor (BF incl) was used to quantify the change from prior inclusion odds to posterior inclusion odds. $\mathrm{BF}_{\text {incl }}$ can be interpreted as the evidence in the data for including a predictor (van den Bergh et al., 2020). For example, a $\mathrm{BF}_{\text {incl }}$ of 50 shows that the data are approximately 50 times more likely under the models that include a predictor than under the models without this predictor. All data were analyzed using Jeffreys's Amazing Statistics Program (JASP, version 0.14.1.0, Netherlands).

\section{Results}

\subsection{State anxiety}

Using a Bayesian repeated measures ANOVA ("default Cauchy prior" of 0.5) with two within-group factors (time $\times$ 
block of unpleasant pictures), the $\mathrm{BF}_{10}$ indicates that the state anxiety level data are $7.53 * 10^{8}$ times more likely under the model that includes only time as the predictor, compared to the null model. Post hoc comparisons of the pre- versus postsession revealed posterior odds of $6.625 * 10^{7}$ against the null hypothesis, which indicates extreme evidence in favor of the alternative hypothesis. Analysis of effects showed no evidence of a time $\times$ block of unpleasant pictures interaction $\left(\mathrm{BF}_{\mathrm{incl}}\right.$ : 0.029) or the main block of pictures effect $\left(\mathrm{BF}_{\text {incl }}\right.$ : 0.037) on state anxiety levels. However, there was extreme evidence of the main time effect $\left(\mathrm{BF}_{\text {incl }}: 5.059 * 10^{7}\right)$, that is, the data are approximately 50.6 million times more likely under the models that include the time factor (pre- versus post-visualization of IAPS unpleasant pictures) than under the models without this predictor. Table 4 shows the model-averaged posterior summary, whereas Table 5 shows the descriptive results about state anxiety levels.

Table 4. Model Averaged Posterior Summary for Bayesian Repeated Measures ANOVA (two within-group factors) on state anxiety levels.

\begin{tabular}{|c|c|c|c|c|c|}
\hline \multirow{2}{*}{ Variable } & \multirow{2}{*}{ Level } & \multirow{2}{*}{ Mean } & \multirow{2}{*}{ Standard deviation } & \multicolumn{2}{|c|}{$95 \%$ Credible Interval } \\
\hline & & & & Lower & Upper \\
\hline Intercept & & 40.626 & 1.557 & 37.430 & 43.668 \\
\hline \multirow[t]{2}{*}{ Time } & Pre & -2.927 & 0.446 & -3.825 & -2.055 \\
\hline & Post & 2.927 & 0.446 & 2.026 & 3.808 \\
\hline \multirow[t]{3}{*}{ Block } & Block 1 & 0.119 & 0.582 & -1.101 & 1.239 \\
\hline & Block 2 & 0.046 & 0.584 & -1.203 & 1.171 \\
\hline & Block 3 & -0.164 & 0.590 & -1.414 & 0.981 \\
\hline \multirow[t]{6}{*}{ Time * Block } & Pre \& Block 1 & -0.424 & 0.572 & -1.575 & 0.725 \\
\hline & Pre \& Block 2 & -0.225 & 0.558 & -1.358 & 0.880 \\
\hline & Pre \& Block 3 & 0.649 & 0.572 & -0.495 & 1.787 \\
\hline & Post \& Block 1 & 0.424 & 0.572 & -0.735 & 1.565 \\
\hline & Post \& Block 2 & 0.225 & 0.558 & -0.891 & 1.347 \\
\hline & Post \& Block 3 & -0.649 & 0.572 & -1.798 & 0.485 \\
\hline
\end{tabular}

Source: Authors.

Table 5. State anxiety levels before and after each block of pictures $(n=37)$.

\begin{tabular}{|c|c|c|c|c|}
\hline & \multirow{2}{*}{ Mean (SD) } & \multirow{2}{*}{ Classification of state anxiety levels } & \multicolumn{2}{|c|}{$95 \%$ credible interval } \\
\hline & & & Lower limit & Upper limit \\
\hline \multicolumn{5}{|l|}{ Block 1} \\
\hline Pre & $37.2(9.4)$ & Intermediate & 34.1 & 40.4 \\
\hline Post & $44.3(11.1)$ & Intermediate & 40.6 & 48.0 \\
\hline \multicolumn{5}{|l|}{ Block 2} \\
\hline Pre & $37.4(10.3)$ & Intermediate & 33.9 & 40.8 \\
\hline Post & $44.0(11.2)$ & Intermediate & 40.2 & 47.7 \\
\hline \multicolumn{5}{|l|}{ Block 3} \\
\hline Pre & $38.2(11.7)$ & Intermediate & 34.3 & 42.1 \\
\hline Post & $42.7(12.0)$ & Intermediate & 38.7 & 46.7 \\
\hline
\end{tabular}

SD: standard deviation. Source: Authors.

Using a Bayesian repeated measures ANOVA ("default Cauchy prior" of 0.5), the $\mathrm{BF}_{01}$ indicates that the changes in state anxiety level data are 2.642 times more likely under the null model compared to the model that includes only blocks of unpleasant pictures as the predictor. Figure 2 shows the absolute and relative increase in state anxiety levels across the three blocks of unpleasant pictures. 
Figure 2. Absolute (A) and relative (B) changes in state anxiety following exposure to blocks 1, 2, and 3. The data are presented as mean \pm credible interval. BF: Bayes factor.
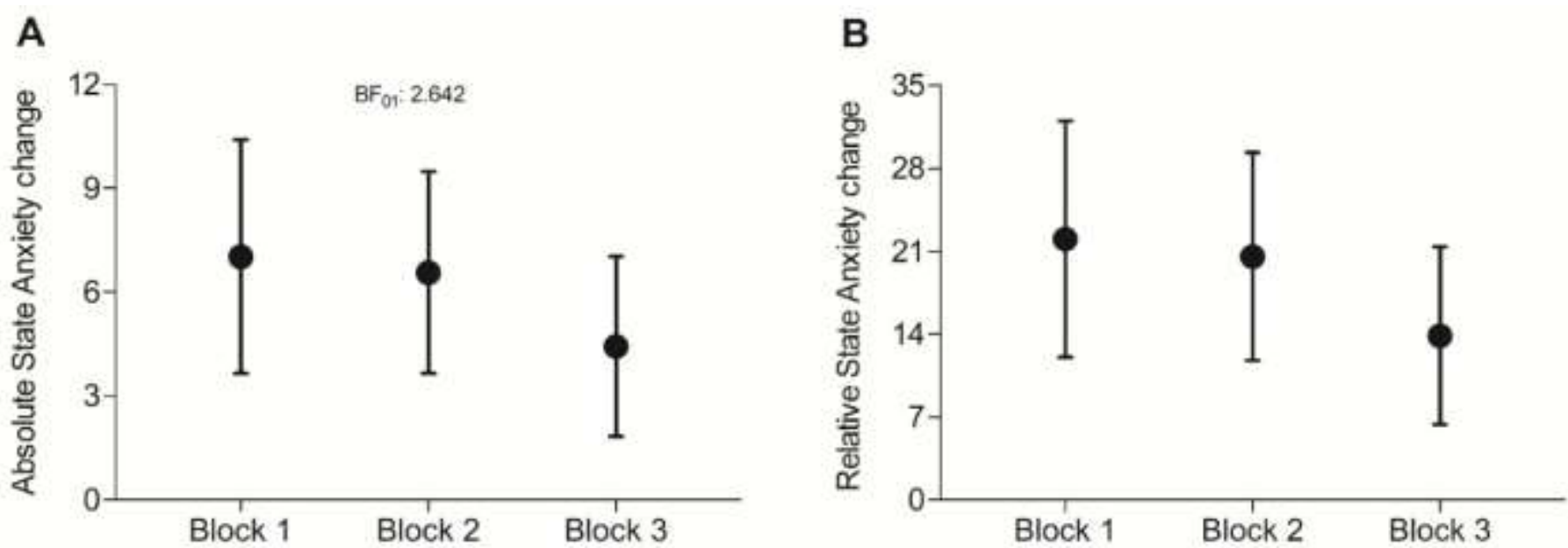

Source: Authors.

\subsection{Affective ratings of picture stimuli}

Using a Bayesian repeated measures ANOVA ("default Cauchy prior" of 0.5), the $\mathrm{BF}_{01}$ indicates that the pleasure, arousal, and dominance domains data are 1.567, 2.609, and 1.954 times, respectively, more likely under the null model compared to the model that includes only blocks of unpleasant pictures as the predictor (Figure 3). Table 6 shows participants' individual affective ratings of picture stimuli (pleasure, arousal, and dominance).

Figure 3. SAM scores on the dimensions of pleasure, arousal, and dominance for each block. SAM: Self-Assessment Manikin. BF: Bayes factors. Data are presented as mean \pm credible interval.

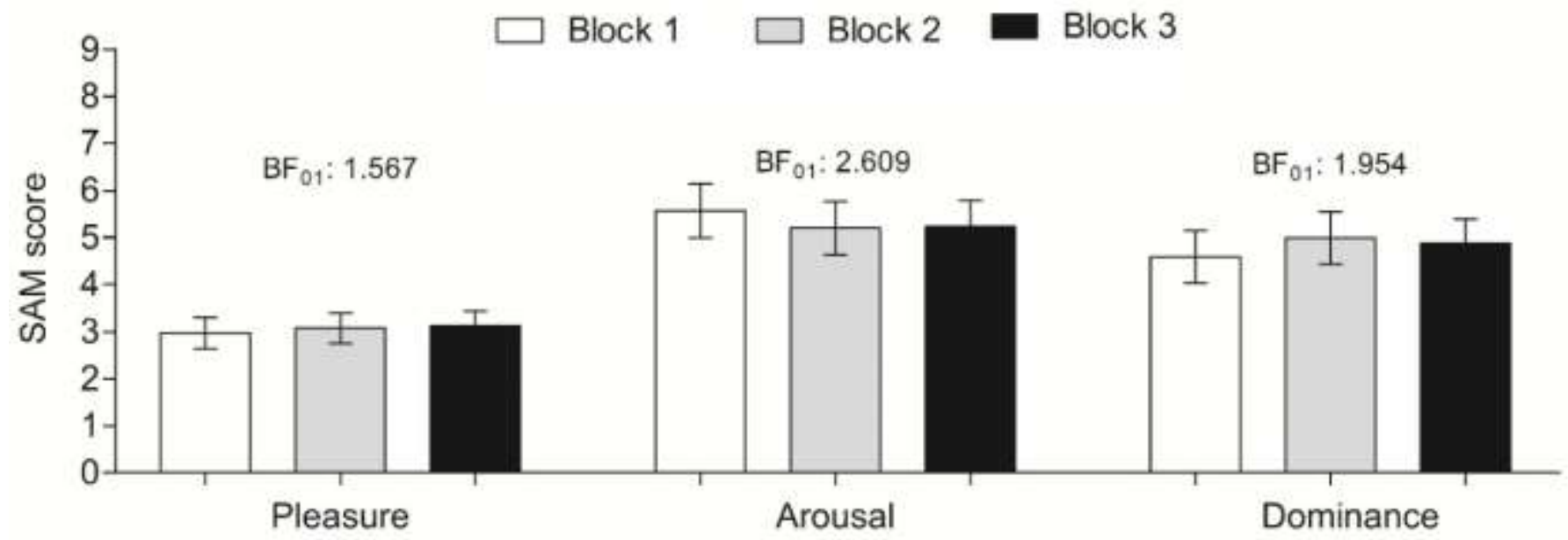

Source: Authors. 
Table 6. Participants' individual affective ratings of picture stimuli.

\begin{tabular}{|c|c|c|c|c|c|c|c|c|c|}
\hline & \multicolumn{3}{|c|}{ Block 1} & \multicolumn{3}{|c|}{ Block 2} & \multicolumn{3}{|c|}{ Block 3} \\
\hline & $\mathrm{P}$ & A & $\mathrm{D}$ & $\mathrm{P}$ & $\mathrm{A}$ & $\mathrm{D}$ & $\mathrm{P}$ & $\mathrm{A}$ & $\mathrm{D}$ \\
\hline Participant 1 & 2.7 & 7.4 & 3.1 & 3.0 & 6.4 & 3.8 & 2.5 & 6.7 & 3.9 \\
\hline Participant 2 & 2.6 & 7.1 & 2.8 & 2.8 & 5.7 & 3.0 & 2.9 & 6.5 & 3.2 \\
\hline Participant 3 & 2.4 & 4.1 & 6.1 & 3.2 & 4.0 & 6.4 & 2.8 & 5.2 & 4.9 \\
\hline Participant 4 & 2.2 & 6.7 & 3.3 & 2.4 & 6.6 & 3.2 & 2.6 & 4.8 & 4.7 \\
\hline Participant 5 & 3.7 & 4.0 & 5.7 & 3.4 & 5.0 & 5.0 & 4.5 & 4.1 & 5.8 \\
\hline Participant 6 & 1.9 & 7.9 & 4.9 & 2.1 & 7.3 & 4.8 & 2.1 & 7.1 & 4.1 \\
\hline Participant 7 & 3.9 & 3.1 & 5.6 & 4.2 & 1.9 & 6.9 & 3.7 & 2.5 & 6.6 \\
\hline Participant 8 & 2.0 & 6.8 & 3.3 & 1.6 & 6.4 & 4.0 & 2.8 & 4.8 & 5.9 \\
\hline Participant 9 & 2.8 & 5.6 & 4.6 & 2.9 & 5.7 & 4.2 & 3.2 & 4.6 & 6.4 \\
\hline Participant 10 & 3.3 & 6.2 & 3.5 & 3.6 & 6.6 & 3.6 & 3.2 & 6.1 & 3.9 \\
\hline Participant 11 & 2.7 & 5.0 & 5.0 & 3.0 & 3.1 & 6.9 & 2.9 & 4.2 & 5.4 \\
\hline Participant 12 & 2.1 & 7.8 & 2.2 & 2.1 & 7.6 & 2.7 & 1.9 & 7.7 & 2.4 \\
\hline Participant 13 & 2.8 & 6.6 & 2.9 & 2.4 & 6.9 & 3.4 & 2.8 & 5.7 & 4.4 \\
\hline Participant 14 & 1.9 & 6.7 & 3.6 & 1.9 & 5.4 & 4.6 & 1.7 & 7.3 & 3.3 \\
\hline Participant 15 & 1.1 & 8.5 & 1.7 & 1.2 & 8.3 & 1.7 & 1.1 & 8.3 & 1.8 \\
\hline Participant 16 & 2.0 & 7.5 & 2.6 & 2.0 & 7.1 & 3.1 & 2.7 & 6.4 & 3.6 \\
\hline Participant 17 & 4.0 & 5.9 & 4.3 & 4.4 & 5.7 & 5.2 & 4.3 & 5.5 & 4.8 \\
\hline Participant 18 & 3.8 & 5.3 & 4.8 & 4.2 & 5.6 & 4.3 & 4.3 & 5.4 & 4.7 \\
\hline Participant 19 & 2.6 & 6.2 & 3.2 & 3.1 & 5.4 & 4.3 & 2.9 & 4.9 & 4.4 \\
\hline Participant 20 & 3.2 & 5.2 & 5.3 & 3.6 & 5.3 & 5.0 & 2.7 & 6.0 & 4.6 \\
\hline Participant 21 & 3.0 & 4.0 & 4.7 & 2.8 & 3.1 & 4.8 & 3.1 & 2.6 & 4.5 \\
\hline Participant 22 & 2.9 & 6.0 & 5.0 & 3.0 & 5.6 & 5.0 & 2.9 & 6.4 & 4.2 \\
\hline Participant 23 & 5.9 & 2.1 & 7.9 & 5.2 & 2.0 & 8.0 & 4.6 & 5.0 & 5.0 \\
\hline Participant 24 & 3.7 & 5.4 & 4.5 & 2.9 & 4.6 & 7.3 & 3.0 & 5.4 & 4.3 \\
\hline Participant 25 & 3.1 & 7.0 & 3.7 & 3.4 & 6.7 & 3.8 & 3.1 & 7.0 & 3.7 \\
\hline Participant 26 & 4.0 & 2.2 & 7.7 & 4.4 & 2.9 & 7.1 & 4.9 & 1.7 & 8.2 \\
\hline Participant 27 & 2.6 & 6.3 & 3.9 & 2.9 & 5.2 & 5.0 & 3.1 & 6.6 & 3.5 \\
\hline Participant 28 & 4.2 & 5.4 & 4.3 & 3.5 & 5.3 & 4.7 & 4.3 & 4.9 & 5.0 \\
\hline Participant 29 & 2.4 & 5.8 & 4.6 & 2.7 & 5.3 & 4.9 & 3.2 & 5.1 & 5.0 \\
\hline Participant 30 & 1.7 & 1.9 & 8.1 & 1.8 & 1.8 & 8.3 & 1.5 & 1.5 & 8.5 \\
\hline Participant 31 & 2.7 & 6.5 & 4.5 & 3.2 & 6.5 & 5.1 & 3.5 & 6.1 & 5.1 \\
\hline Participant 32 & 1.8 & 6.7 & 3.4 & 1.5 & 6.8 & 3.4 & 1.5 & 6.1 & 4.5 \\
\hline Participant 33 & 4.9 & 2.0 & 9.0 & 4.8 & 2.0 & 9.0 & 4.4 & 1.8 & 9.0 \\
\hline Participant 34 & 2.3 & 6.4 & 4.4 & 2.6 & 5.4 & 5.5 & 2.9 & 6.1 & 4.4 \\
\hline Participant 35 & 4.4 & 5.7 & 3.9 & 4.6 & 5.6 & 4.5 & 4.5 & 5.4 & 4.5 \\
\hline Participant 36 & 3.2 & 3.5 & 6.8 & 4.0 & 3.0 & 7.2 & 4.2 & 2.8 & 7.3 \\
\hline Participant 37 & 3.4 & 5.3 & 4.4 & 3.6 & 5.0 & 5.0 & 3.6 & 4.9 & 5.2 \\
\hline
\end{tabular}

P: pleasure; A: arousal; D: dominance. Source: Authors.

\subsection{Heart rate}

Using a Bayesian repeated measures ANOVA ("default Cauchy prior" of 0.5), the $\mathrm{BF}_{01}$ indicates that the mean heart 
rate data are 7.449 times more likely under the null model compared to the model that includes only blocks of unpleasant pictures as the predictor (Figure 4A). Figure 4B shows overall mean heart rate behavior during the blocks of unpleasant pictures.

Figure 4. Mean heart rate $(\mathrm{A})$ in each block (mean \pm credible interval) and overall mean heart rate behavior of the participants during the blocks $(n=37)$. BF: Bayes factor.

A

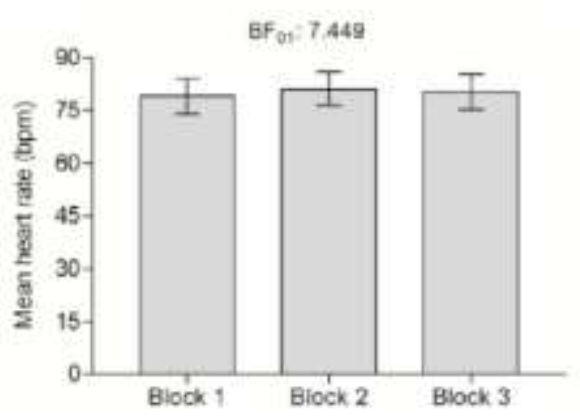

B

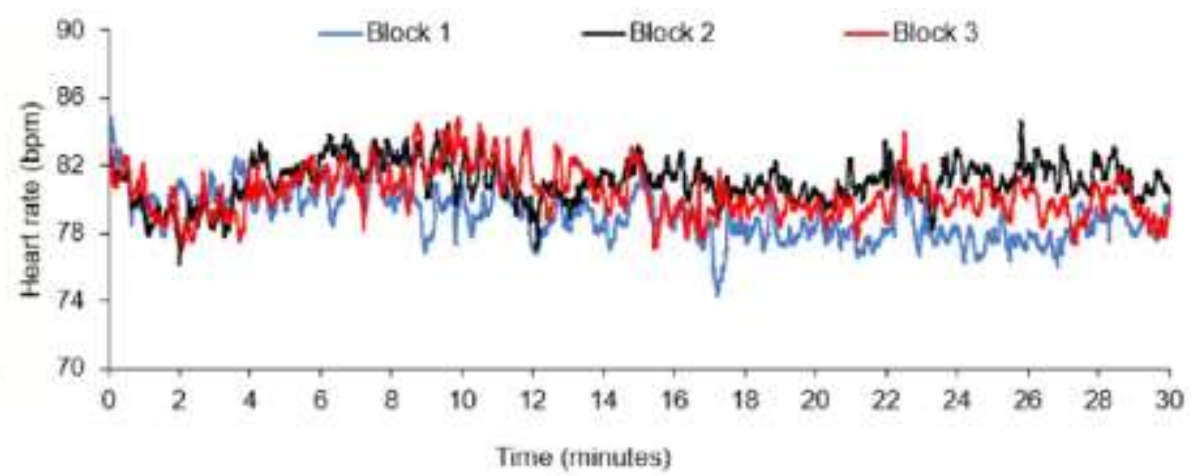

Source: Authors.

\section{Discussion}

We investigated changes in anxiety levels in healthy women following exposure to three blocks of unpleasant pictures from the IAPS. Our results indicated extreme evidence $\left(\mathrm{BF}_{10}\right.$ of $\left.7.53^{*} 10^{8}\right)$ for the changes in the participants' state anxiety after viewing the IAPS unpleasant pictures. However, the results revealed ambiguous evidence $\left(\mathrm{BF}_{01}\right.$ of 2.642) favoring similar changes in state anxiety and ratings of pleasure $\left(\mathrm{BF}_{01}\right.$ of 1.567$)$, arousal $\left(\mathrm{BF}_{01}\right.$ of 2.609), and dominance $\left(\mathrm{BF}_{01}\right.$ of 1.954$)$ between the three blocks of unpleasant pictures used. Moreover, we found moderate evidence $\left(\mathrm{BF}_{01}\right.$ of 7.449$)$ favoring similar mean heart rates between the three blocks of unpleasant pictures used.

Regarding increases in anxiety levels after exposure to visual stimuli, Smith (2013) examined individuals (men and women) with similar trait anxiety levels $(45.7 \pm 3.4$, as measured by the STAI) and found an increase of approximately $12 \%$ $(28.4 \pm 8.4$ versus $31.8 \pm 10.2)$ in anxiety levels after exposure to IAPS pictures. Thus, the increases in anxiety state levels in the present study after viewing the three blocks of unpleasant pictures (14\% to $22 \%$ ) determined in this study are higher than those found by Smith (2013). We also recorded slightly higher mean heart rate values (79 bpm to 81 bpm) compared with the heart rate values (approximately $73 \mathrm{bpm}$ ) recorded in Smith's study (Smith, 2013). These differences may be attributed to the fact that we used blocks of unpleasant pictures only, whereas Smith (2013) used three blocks composed of pleasant, neutral, and unpleasant IAPS pictures.

In this context, based on our current findings, the three blocks of unpleasant IAPS pictures used in the present study could be randomly allocated to different sessions in a repeated measures intervention study (within-groups study design) aimed at increasing anxiety levels in healthy women, followed by pharmacological and/or nonpharmacological interventions to reduce anxiety levels. This could be a useful strategy for simulating higher levels of anxiety and avoiding the "ground effect" common to experimental studies involving nonclinical populations. This is critical because for many researchers it is not easy to recruit people with a clinical diagnosis of anxiety. More precisely, it may allow the researchers to perform their experiments in an induced-anxiety population (mimicking a clinical population). Moreover, it could prevent the need to use the same block of unpleasant pictures in all experimental sessions. If the same block is used in all sessions, participants in this type of study 
design may get used to the pictures, leading to increased bias. However, if the goal is to use blocks of unpleasant pictures for a between-group study design, we suggest using the same block of unpleasant pictures since each group will consist of different participants.

As reported previously, we used only unpleasant pictures from the IAPS. This was because exposure to unpleasant pictures has a more considerable effect on anxiety in healthy individuals than exposure to pleasant and neutral pictures (Smith et al., 2005). Moreover, there is evidence of a higher mean startle magnitude (microvolts) during and after rapidly presented (three and seven pictures per second) blocks of unpleasant pictures in introductory psychology students (Smith et al., 2006).

Many physiological mechanisms have been proposed to explain an increase in anxiety as a result of unpleasant exposure. Briefly, the physiological mechanisms include alterations in cortisol release and autonomic responses (heart rate and skin conductance) (Smith et al., 2005). For example, Smith et al. (2005) evaluated the effects of sustained exposure to emotional stimuli on affective reactions. Furthermore, recovery was examined to determine whether increasing exposure to an emotional stimulus (e.g., unpleasant) cumulatively affects physiological variables and whether motivational activation persists following sustained exposure. The authors found that startle magnitude showed higher potentiation and corrugator electromyography activity increased as a consequence of exposure to unpleasant pictures. Furthermore, the study revealed more skin conductance responses during exposure to unpleasant pictures as compared to other pictures (pleasant and neutral). In addition, the heart rate increased after exposure to unpleasant pictures. Fiksdal et al. (2019) investigated the hypothalamicpituitary-adrenal axis response (salivary cortisol) to stress induced by the Trier Social Stress Test and demonstrated that stress elicited cortisol response. Unfortunately, no assessment of any of the above-mentioned mechanisms was conducted in the present study. However, albeit speculative, it is reasonable to assume that similar physiological responses can be triggered by our experimental procedures.

The present study has several limitations. First, although the IAPS is an easy and efficient tool for inducing anxiety responses in laboratory settings (Smith et al., 2005), its use in the anxiety disorders population is highly limited (Jayaro et al., 2008). Adults with anxiety disorders may respond differently than healthy individuals. Therefore, similar studies should be conducted on clinical populations. Second, contraceptives are known to impact oxytocin, which is involved in social and emotional behavior (Scheele et al., 2016); however, almost all participants using contraceptives methods were taking monophasic contraceptives, which provide a fixed hormone dose per day. Third, as the IAPS has over 1,800 pictures and in the present study only 207 unpleasant pictures were used over three blocks, it remains unknown whether the remaining unpleasant pictures would induce similarly elevated anxiety levels. Four, although evidence suggests a similar increase in state anxiety levels across the blocks of unpleasant pictures, participants remained within the intermediate level of state anxiety. Five, there was no control session composed by only neutral pictures. However, our study is a pilot study aimed to collect preliminary data about the effect of only unpleasant picture exposure on state anxiety. Furthermore, we used the within-subject effect approach (i.e., before versus after), implying that each participant had control. Given that previous studies showed an increase in emotional aspects using a mixed set of pictures (constituted by neutral, unpleasant and pleasant pictures), it is reasonable to assume that only exposure to unpleasant pictures would elicit similar or higher effects. Finally, we found ambiguous evidence $\left(\mathrm{BF}_{01}\right.$ between 0.33 and 3) to draw conclusions about the pleasure, arousal, and dominance rating of the unpleasant pictures between the blocks of unpleasant pictures used. More precisely, the $\mathrm{BF}_{01}$ values approaching 1 indicated that there is not enough evidence to prefer either null or alternative hypothesis, which may be due to relatively small sample size. However, our overall values for the pleasure, arousal, and dominance ratings for each unpleasant picture (Figure 3 and Table 6) used are in accordance with their respective values in the IAPS manual (Table 3) (Lang et al., 2008b). 


\section{Conclusion}

The study findings indicated that exposure to unpleasant pictures acts as an anxiogenic stimulus that can be used to induce experimental anxiety. Furthermore, as adults with anxiety disorders may respond differently than healthy individuals, future studies enrolling different populations are needed.

\section{Acknowledgments}

We would like to thank all the participants in our study for generously offering their time. This study was supported by the Fundação de Amparo à Pesquisa do Estado de Goiás-FAPEG/Brazil (grant number: 201210267001056), the Conselho Nacional de Desenvolvimento Científico e Tecnológico-CNPq/Brazil (grant number: 405096/2016-0) and Coordenação de Aperfeiçoamento de Pessoal de Ensino Superior/Brazil (Finance code 001). CABL is a productivity fellowship at the Conselho Nacional de Desenvolvimento Científico e Tecnológico (CNPq, Brazil, grant number: 305276/2020-4). The funders had no role in study design, data collection and analysis, decision to publish, or preparation of the manuscript.

\section{Author Contribution Statement}

RBV and CABL: conceived and designed research. RBV and LCA conducted experiments. RBV analyzed data wrote the manuscript. RBV, NSM, TGC, LCA, WFS, DATS and CABL revised the manuscript. All authors read and approved the final version of the manuscript.

\section{References}

American P. A. (2013). DSM-5: Diagnostic and Statistical Manual of Mental Disorders. Washington DC: American Psychiatric Association. 947.

Bandelow, B., \& Michaelis, S. (2015). Epidemiology of anxiety disorders in the 21st century. Dialogues in Clinical Neuroscience, 17(3), 327-335.

Charney, D. S., Galloway, M. P., \& Heninger, G. R. (1984). The effects of caffeine on plasma MHPG, subjective anxiety, autonomic symptoms and blood pressure in healthy humans. Life Sciences, 35(2), 135-144. https://doi.org/10.1016/0024-3205(84)90132-2

Cuthbert, B. N., Bradley, M. M., \& Lang, P. J. (1996). Probing picture perception: activation and emotion. Psychophysiology, 33(2), 103-111. https://doi.org/10.1111/j.1469-8986.1996.tb02114.x

Fiksdal, A., Hanlin, L., Kuras, Y., Gianferante, D., Chen, X., Thoma, M. V., \& Rohleder, N. (2019). Associations between symptoms of depression and anxiety and cortisol responses to and recovery from acute stress. Psychoneuroendocrinology, 102, 44-52. https://doi.org/10.1016/j.psyneuen.2018.11.035

Gorenstein, C., \& Andrade, L. (1996). Validation of portuguese version of the Beck depression inventory and the state-trait anxiety inventory in brazilian subjects. Brazilian Journal of Medical and Biological Research, 29(4), 453-457.

Jayaro, C., de la Vega, I., Díaz-Marsá, M., Montes, A., \& Carrasco, J. L. (2008). The use of the International Affective Picture System for the study of affective dysregulation in mental disorders. Actas Espanolas de Psiquiatria, 36(3), 177-182.

Lang, P., Bradley, M., \& Cuthbert, B. (1997). International Affective Picture System (IAPS): technical manual and affective ratings. NIMH Center for the study of Emotion and Attention.

Lang, P., Bradley, M., \& Cuthbert, B. (2008a). International Affective Picture System ( IAPS ): Affective reatings of pictures and instruction manual. In Technical Report A-8.

Lang, P., Bradley, M., \& Cuthbert, B. (2008b). International Affective Picture System (IAPS): affective ratings of pictures and instruction manual. In Technical Report A-8.

Lasaitis, C., Ribeiro, R. L., \& Bueno, O. F. A. (2008). Brazilian norms for the International Affective Picture System (IAPS): comparison of the affective ratings for new stimuli between Brazilian and North-American subjects. Jornal Brasileiro de Psiquiatria, 57(4), 270-275. https://doi.org/10.1590/S004720852008000400008

Mondin, T. C., Konradt, C. E., Cardoso, T. de A., Quevedo, L. de A., Jansen, K., Mattos, L. D. de, Pinheiro, R. T., \& Silva, R. A. da. (2013). Anxiety disorders in young people: a population-based study. Revista Brasileira de Psiquiatria, 35(4), 347-352. https://doi.org/10.1590/1516-4446-2013-1155

Motl, R. W., \& Dishman, R. K. (2004). Effects of acute exercise on the soleus H-reflex and self-reported anxiety after caffeine ingestion. Physiology \& Behavior, 80(4), 577-585. https://doi.org/10.1016/j.physbeh.2003.10.015

Nillni, Y. I., Toufexis, D. J., \& Rohan, K. J. (2011). Anxiety sensitivity, the menstrual cycle, and panic disorder: a putative neuroendocrine and psychological interaction. Clinical Psychology Review, 31(7), 1183-1191. https://doi.org/10.1016/j.cpr.2011.07.006 
Research, Society and Development, v. 10, n. 16, e505101624153, 2021

(CC BY 4.0) | ISSN 2525-3409 | DOI: http://dx.doi.org/10.33448/rsd-v10i16.24153

NIMH. (2016). Any anxiety disorder among adults. National Institute of Mental Health. https://www.nimh.nih.gov/health/statistics/prevalence/any-anxietydisorder-among-adults.shtml

Peterson, R., \& Reiss, S. (1987). Test manual for the anxiety sensitivity index. Orland Park, IL: International Diagnostic Systems.

Sarlo, M., Buodo, G., Poli, S., \& Palomba, D. (2005). Changes in EEG alpha power to different disgust elicitors: the specificity of mutilations. Neuroscience Letters, 382(3), 291-296. https://doi.org/10.1016/j.neulet.2005.03.037

Scheele, D., Plota, J., Stoffel-Wagner, B., Maier, W., \& Hurlemann, R. (2016). Hormonal contraceptives suppress oxytocin-induced brain reward responses to the partner's face. Social Cognitive and Affective Neuroscience, 11(5), 767-774. https://doi.org/10.1093/scan/nsv157

Smith, J. C. (2013). Effects of emotional exposure on state anxiety after acute exercise. Medicine \& Science in Sports \& Exercise, 45(2), 372-378. https://doi.org/10.1249/MSS.0b013e31826d5ce5

Smith, J. C., Bradley, M. M., \& Lang, P. J. (2005). State anxiety and affective physiology: effects of sustained exposure to affective pictures. Biological Psychology, 69(3), 247-260. https://doi.org/10.1016/j.biopsycho.2004.09.001

Smith, J. C., Löw, A., Bradley, M. M., \& Lang, P. J. (2006). Rapid picture presentation and affective engagement. Emotion, 6(2), 208-214. https://doi.org/10.1037/1528-3542.6.2.208

Spielberger, C. (1989). State-Trait Anxiety Inventory: Bibliography (2nd ed.). Consulting Psychologists Press.

Taylor, C. B., Sheikh, J., Agras, W. S., Roth, W. T., Margraf, J., Ehlers, A., Maddock, R. J., \& Gossard, D. (1986). Ambulatory heart rate changes in patients with panic attacks. American Journal of Psychiatry, 143(4), 478-482. https://doi.org/10.1176/ajp.143.4.478

van den Bergh, D., van Doorn, J., Marsman, M., Draws, T., van Kesteren, E.-J., Derks, K., Dablander, F., Gronau, Q. F., Kucharský, Šimon, Gupta, A. R. K. N., Sarafoglou, A., Voelkel, J. G., Stefan, A., Ly, A., Hinne, M., Matzke, D., \& Wagenmakers, E.-J. (2020). A Tutorial on conducting and interpreting a Bayesian ANOVA in JASP. L'Année Psychologique, 120(1), 73. https://doi.org/10.3917/anpsy1.201.0073

van Doorn, J., van den Bergh, D., Böhm, U., Dablander, F., Derks, K., Draws, T., Etz, A., Evans, N. J., Gronau, Q. F., Haaf, J. M., Hinne, M., Kucharský, Š., Ly, A., Marsman, M., Matzke, D., Gupta, A. R. K. N., Sarafoglou, A., Stefan, A., Voelkel, J. G., \& Wagenmakers, E.-J. (2020). The JASP guidelines for conducting and reporting a Bayesian analysis. Psychonomic Bulletin \& Review, 1-38. https://doi.org/10.3758/s13423-020-01798-5

van Doorn, J., \& Wagenmakers, E. (2020). Bayesian inference in JASP: a guide for students. Mark A Goss-Sampson. https://doi.org/10.17605/OSF.IO/CKNXM

Wagenmakers, E.-J., Love, J., Marsman, M., Jamil, T., Ly, A., Verhagen, J., Selker, R., Gronau, Q. F., Dropmann, D., Boutin, B., Meerhoff, F., Knight, P., Raj, A., van Kesteren, E.-J., van Doorn, J., Šmíra, M., Epskamp, S., Etz, A., Matzke, D., ... Morey, R. D. (2018). Bayesian inference for psychology. Part II: Example applications with JASP. Psychonomic Bulletin \& Review, 25(1), 58-76. https://doi.org/10.3758/s13423-017-1323-7

Youngstedt, S. D., O’Connor, P. J., Crabbe, J. B., \& Dishman, R. K. (1998). Acute exercise reduces caffeine-induced anxiogenesis. Medicine \& Science in Sports \& Exercise, 30(5), 740-745. https://doi.org/10.1097/00005768-199805000-00015 